\title{
Teachers Creating Effective Learning Experiences for Indigenous Learners
}

\author{
Lindsey Conner ${ }^{1}$, Judith Bennetts ${ }^{2}$ \\ ${ }^{1}$ College of Education, Psychology \& Social Work, Flinders University, Adelaide, SA, Australia \\ ${ }^{2}$ College of Education, Health and Human Development, University of Canterbury, Christchurch, New Zealand \\ Email: Conner@flinders.edu.au, judith.bennetts@canterbury.ac.nz
}

How to cite this paper: Conner, L., \& Bennetts, J. (2018). Teachers Creating Effective Learning Experiences for Indigenous Learners. Creative Education, 9, 1000-1019. https://doi.org/10.4236/ce.2018.96074

Received: February 2, 2018

Accepted: May 28, 2018

Published: May 31, 2018

Copyright (c) 2018 by authors and Scientific Research Publishing Inc. This work is licensed under the Creative Commons Attribution International License (CC BY 4.0).

http://creativecommons.org/licenses/by/4.0/

\begin{abstract}
"Recently professional learning and development has turned a corner. Teachers as leaders of learning have realized that they can be agents of change within their classrooms by focusing on quite specific teaching changes to improve outcomes for their learners" (Conner, 2015: p. 7). This paper provides examples of how teachers were challenged to link changes in their practice to include good principles of indigenous pedagogies (through participating in cycles of teaching and inquiry), to changes in students' outcomes, which has rarely been reported previously. Vignettes of changes teachers made to their teaching were gathered as they responded to reflections and support from mentors and used student achievement data as tools for inquiry. Teachers were provoked to be more aware of the importance of evidence-informed critical reflection on pedagogical development that was appropriate for indigenous students. We provide an overall analysis and vignette examples to illustrate the emerging themes which were: the development of positive professional relationships (mentor-teacher, teacher-teacher and teacher-student), developing pedagogical knowledge that was appropriate for indigenous students that was also informed by seeking student and whānau (family) voice or feedback to inform changes to teaching.
\end{abstract}

\section{Keywords}

Indigenous Learners, Teaching as Inquiry, TAI, Mentors

\section{Introduction}

The New Zealand's Ministry of Education's vision statement is "to see all children and students succeed personally and achieve educational success" (Ministry of Education, 2016: p. 2). There is a sizeable body of evidence (Committee, 
House of Representatives Education and Science, 2008; Ell \& Grudnoff, 2013) that shows that in education New Zealand has a long tail of underachievement. The evidence is clear that Māori and Pasifika students are over represented amongst students who are underachieving in school science as well as in other subjects (Cooper, 2012; Committee, House of Representatives Education and Science, 2008; Ministry of Education, 2009a). The research reported here was part of the evaluation of a larger project called the Secondary Student Achievement Project (Mau ki te ako) funded by the New Zealand Ministry of Education. The full report (Conner, 2015) provides background and a much broader cross-curricular context in which this project occurred. In this intervention, subject-specific mentors supported teachers to change their approaches and to observe and report vignettes in relation to four to six learners. This focus on priority learners (Māori, Pasifika, low socio-economic status or students with high learning needs) was a result of a clear moral imperative that the achievement gap needed to be addressed. As well, it was considered that what was learned from changing approaches with priority learners could be applied to many other learners as well. Although the examples here come from secondary science schooling in New Zealand, what was learned can be applied to other education sectors and is relevant to education systems beyond New Zealand.

The research approach used appreciative inquiry to investigate how teachers could implement and reflect on changes to their teaching and how these changes led to improved student outcomes. Appreciative inquiry has both a focus on the positive outcomes (for teachers and students) and identifying the collaborations essential for enabling success. This approach has been used and reported previously as a way to support and build professional learning (Jansen, Cammock, \& Conner, 2010) whilst simultaneously using the conversations, teachers' records and narratives of changes and outcomes as research data sources. The "accentuation of the positive" characteristic of appreciative inquiry aligns well with a strengths-focused orientation as part of positive psychology, which has a growing influence on research and practice across the human service sectors. Naturally, there were challenges experienced by teachers and we discuss aspects of implementation that resulted in variations in levels of success. Teachers and leaders needed time to develop their reflective capacities, to trial changes in response to the learning data generated from their students learning activities and to consider other relational aspects that were important for indigenous learners.

\section{Professional Learning through Inquiry}

Historically, professional learning and development (PLD) for more effective teaching took the form of short courses or one-off events whereby teachers learnt something new and then incorporated the ideas into practice. This was content and skills-focused PLD that tended to assume teachers would be able to modify their teaching to accommodate the new knowledge they had learnt without on-going support. In contrast, Teaching as Inquiry (TAI) is a more iter- 
ative process related to teachers' critical reflection (Brookfield, 1995), where teachers make on-going refinements to their teaching decisions and actions based on observations and evidence of their students' learning (Timperley, 2011). TAI is learning-centered from the learning perspective of both students and teachers, and was derived from Dewey's (1933) understanding of learning as being holistic and integral with experience. This is what Webster-Wright (2009) proposed as authentic professional learning because it is situated directly in and relates to teachers' specific concerns related to their experiences of enabling their students' learning. Further, Dewey's (1933) conceptions of "creative action" and "theory of inquiry" have expanded our use of experience, reflection and context to further extend PLD that is based on teachers' own creative ideas being applied to interventions. There is quite extant research to illustrate the benefits of professional learning when it is based on reflection and changing practice that is contextually mediated (Day, 1999; Garet, Porter, Desimone, Birman, \& Yoon, 2001; Lieberman \& Miller, 2001; Webster-Wright, 2009). In the context of this study, teachers had the ability to apply their own creative effort to the design of their programs and how they provided engaging and appropriate learning activities for students.

While The New Zealand Curriculum (Ministry of Education, 2007) is nationally mandated and implemented, it provides guidelines for teachers as to values, competencies to develop and general scope for what to teach spanning levels of achievement. Curriculum support materials are also provided for teachers through Ministry of Education websites (e.g. http://www.tki.govt.nz/). Teaching in the NZ compulsory education sector requires teachers to develop their own localized curriculum and emphasizes that teachers need to know their learners so they can design and create learning experiences that have contexts and examples that relate personally to their students. In this respect teachers in NZ are expected to be creative designers of learning. In general, they have only more recently realized the power of this for addressing the needs of indigenous learners and for addressing cultural aspects of learners and learning more specifically (Conner, 2015).

In New Zealand, TAI is an integral part of The New Zealand Curriculum (Ministry of Education, 2007) and is emphasized as a way to improve student outcomes in New Zealand schools (Ministry of Education, 2009a). It is positioned as an essential part of teaching and review or professional growth. The confusion about what TAI actually is or can be, and how to put it into practice (Benade, 2015; Education Review Office, 2011, 2012; Sinnema \& Aitken, 2011) is being developed in the majority of primary and secondary schools whereby examples and exemplars are supporting teachers to take action creatively and to reflect on how evidence of student outcomes leads to further actions (Conner \& Bennetts, 2016; Conner, 2013). Therefore TAI provides flexibility and requires iterations or negotiations between teachers and mentors as a very negotiated approach to professional learning and development. 
TAI is more than simply critically reflecting on practice and identifying the consequential learning needs of teachers. In the NZ school system, where individualized attention to progress and differentiated learning is highly valued (Ministry of Education, 2007), there was a need to align the TAI process more closely with student-centered approaches to teaching and to keep it manageable. This coincided with the shifts in emphasis internationally, to put students at the center of learning (OECD, 2010, 2013) and to consider the consequent shifts needed for teacher education for evidence-informed practice (Conner \& Sliwka, 2014). As a result of these shifts, the Ministry saw the need to support TAI development in schools, as it had potential to realize more system-wide shifts in students' outcomes, particularly for indigenous learners and support professional learning simultaneously.

When TAI was first introduced in NZ schools, it was seen as a vehicle to empower teachers to take on responsibility for their own professional learning and make changes to their practice, rather than passively accepting, modifying or rejecting others' expertise (Timperley, Wilson, Barrar, \& Fung, 2007). However, for good reasons, school leaders also wanted all teachers in their schools to engage with TAI, but were not sure how to support them with evidence-informed practices or steps to redesign teaching within learning areas. Empowerment for change comes when people are provided with choice and some self-selection or ability to choose what they can do to implement that. In contrast, when TAI was driven from a whole school perspective as a mandated endeavor, it tended to be focused on key areas of concern such as literacy development, use of ICT tools and other more general concerns at a school level. In many cases this led to the development of professional learning groups or professional learning communities within schools to focus on common concerns, often across a range of learning areas. While this approach ensured that all teachers belonged to a "group", it did not provide sufficient flexibility for teachers to determine what was important for the students they needed to focus on nor did it provide pedagogy that was focused on specialized learning areas (Conner, 2015). TAI is not a prescribed program for teachers to follow but is an adaptive process approach whereby teachers can modify what they do according to their skills and the needs of their students. In other words, initially TAI used a concept approach that was common to a group of teachers for professional learning (e.g. use of technology for learning), or for developing critical or creative thinking more generically across learning areas. This was in contrast to what it evolved to be a student-centered approach based on the needs of specific students in the subject context in which they were learning.

Previously the model of TAI as presented in The NZ Curriculum has been critiqued as being focused on individual teacher's development (Bernade, 2015). The focus of TAI is usually on any inconsistencies between what is intended and what actually occurs (Timperley, 2011). However in the model of TAI that we used, teachers started with observations of their $4-6$ priority students' needs as 
the starting point and then teachers derived their own actions with the support of a subject-specific mentor and/or subject colleagues to try to address these needs. Focusing on 4 - 6 priority learners was developed as a way to manage TAI for a more in-depth approach that targeted indigenous learners in particular (Conner, 2015).

\section{Developing Culturally Appropriate Pedagogy}

Worldwide it is recognized that creating effective learning experiences for indigenous learners is pressingly urgent. Blankstein and Noguera (2015: p. 7) insist that "demography need not determine destiny, and a child's race and class can be decoupled from how well they do in school or college". We need to find ways for indigenous people to succeed. As stated in Conner (2015: p. 9) "of prime interest is how (and whether) teachers and schools consider that all students have latent talents that can be enhanced" and how we identify and take action to redress the inequities for children who do not have access to resources (time, knowledge, skills and/or money) for their talents to be developed.

There have been huge strides in identifying what does make a difference for indigenous learners in NZ education contexts and internationally. In NZ, this is reflected in the high level national curriculum document (Ministry of Education, 2007) with multiple supporting materials, such as Tataiako (New Zealand Teachers Council, 2010), The Pasifika Education Plan (Ministry of Education, 2012a) and Ka Hikitia-Accelerating Success 2013-2017 (Ministry of Education 2012b). These documents provide suggestions for developing and refining teachers' understanding about cultural competence. School leaders are very aware of the importance of culturally appropriate communication, how a sense of belonging can be created through the visual artifacts showcased around the school, and how relationships among staff and between staff and students can support cultural aspirations. A previous research project (Cowie et al., 2011) that focused on primary science found that:

- Learning and assessment in science needed to provide and privilege diverse ways for children to express, develop and gain feedback on their growing knowledge and expertise.

- Teaching and learning science was enriched when teachers created opportunities to connect learning activities with children's and communities' lived experiences.

However, there is still much work to be done, so that teachers can embrace their role in designing experiences that are responsive to diverse identities, languages and cultures so that our future citizens lead meaningful lives.

Teachers in this Ministry-funded Mau ki te Ako project, prioritized their focus on developing students' subskills, and responded to the needs of their learners through finding out more about their learning needs and their personal preferences. They also became better at guiding students to be more actively involved in self-assessing and directing their own learning. In this way they devel- 
oped what Hipkins (2015) describes as students' assessment capability, because students became much more familiar with the expectations and requirements of assessments.

PLD mentors noted that many teachers find developing appropriate culturally responsive pedagogies a challenge. Some teachers do not have an adequate knowledge of what culturally responsive pedagogy is. But even if they have knowledge, putting this into practice can be difficult, even when teachers have engaged in programs within their schools, such as Kia Eke Panuka (KEP), which was part of the "Building on Success" school reform initiative operating in 93 secondary schools across New Zealand. KEP supports developing contexts for learning where learners are able to connect new learning to their prior knowledge and cultural experiences. One science mentor observed a teacher in a KEP school teaching a geology unit. The class discussed where the water came from for their city but the teacher did not think to ask the Pasifika students where their water came from. Making links to the Pasifika student's cultural knowledge would possibly have engaged this student more in the discussion.

As a teacher explained, for her, culturally responsive pedagogy is all about how you engage (relate) with students in your teaching. Changes to her practice included shifting from her telling knowledge to where she sought information through questioning, about students' prior knowledge, needs and interests. For example, instead of teaching the students about the energy in food and doing experiments as she has done for many years, the teacher asked students what they have in their lunchbox, as a hook or starter for further conversations about the amount of calories in certain foods and nutritional content.

In this Ministry of Education funded TAI implementation (Mau ki te Ako) project in 47 secondary schools in New Zealand, subject-specific mentors supported teachers to identify the needs of $4-6$ priority learners. These priority learners were Māori and Pasifika students who had been identified as being "at risk" of not achieving, learners with special education needs and those from low socio-economic backgrounds. The teachers involved in the project were supported to implement their professional goals in relation to their students' needs and to link these changes in practice to students' outcomes. The mentors provided specific, concrete and practical ideas that related directly to the needs of students to advance students' learning in specific subjects, similar to what has been reported more generally about mentoring by Akharvan (2015), Guskey (2003) and Timperley, Wilson, Barrar and Fung (2007). Teachers and middle leaders collaborated in teams within schools and inquiry clusters, both within and across schools to build capability and capacity for culturally appropriate pedagogy. The research was designed to address the research questions: "how did teachers creatively develop solutions for implementing culturally appropriate practice?"

\section{Methodology and Research Methods}

We used an appreciative inquiry approach for this research. Appreciative inquiry involves people collaborating to ask questions that are likely to build a sys- 
tem's capacity to extend the system's capacity and capability. In essence, it is a systematic discovery about what enables a living system to function well, enhance it and sustain it (Cooperrider, Sorensen, Whitney, \& Yager, 2000). It is an inquiry process that generates theory (in this project of teaching practice in relation to indigenous learners). It is a qualitative process using a range of artifacts generated by the participants in the system. Therefore, it is considered to be particularly appropriate for investigating professional learning and development and may in fact provide a transformative element, where through conducting the research leads to changes in outcomes that would not have been identified nor revealed had the research not taken place. The collaborative nature of this inquiry process, between teachers, between teacher leaders and other teachers and between mentors and teachers enabled the inquiry to be mindful of culturally appropriate negotiations that had to be considered in terms of setting up and managing the research process.

The research and professional learning approach was developed in partnership with runanga as the Mau ki te Ako project through a consortium, Te Tapuae o Rehua (University of Canterbury, University of Otago and Ngai Tahu team). TAI enabled the teachers within each of the forty-seven schools, to continuously customize and appropriate their teaching in relation to the specific needs of the students they taught and their professional learning needs, over five years so far. The challenges that arose were discussed as part of the ongoing leadership of TAI as a whole school approach to PLD and with individual teachers as they developed specific ideas, trialed them and reflected on success or potential challenges, as part of their everyday teaching. The project report has been published previously (Conner, 2015) but in this paper we focus on the creative elements of science teachers' practice as they redesigned their teaching in culturally appropriate ways.

Mixed qualitative methods were used. Firstly, mentors and middle leaders (Heads of Departments) were asked to write vignettes of changes to practice and to link this to specific learning outcomes for them as teachers/leaders or describe how this led to changes in students' achievement. Selected middle leaders were also interviewed. Focus group discussions between middle leaders and mentors also contributed to the data sources. These were then analyzed thematically to derive broad categories for organizing and conveying the findings. Due to the working relationships between mentors and middle leaders, the vignettes and descriptions of changes to practices and outcomes were sent to the senior author of this paper and the anonymity of the participants was assured. Ethical approval was obtained through the University of Canterbury's Human Ethics Committee and the conditions and ideals of ethical research were applied throughout the research process.

\section{Data Analysis}

Analysis of data (written descriptions) from mentors and middle leaders, reflec- 
tive conversations, interviews and other artifacts (e.g. notes of meetings) were coded for themes related to teacher professional learning and what made a difference in specific contexts. These were used to develop broad categories that seemed to reflect answers to the research question-what factors influence teachers' changes to their practices and how does this influence students' outcomes (broadly)?

The teachers' descriptions of the creative ways in which they had modified their teaching and vignettes from teachers and mentors were coded and sorted into themes. Selected excerpts were chosen to represent effective changes. These were member-checked with the participants and cross-checked between researchers. Examples of these in-depth descriptions are included within the discussion of each of the emergent themes related to changes in teaching in the next section.

\section{Findings}

The themes that emerged in relation to success factors for teachers redesigning their pedagogies to make them more culturally appropriate were the importance of developing:

1) Positive professional relationships

2) Knowledge about subject content, pedagogies and implementing changes

3) Student and whānau (family) contributions to inform changes to teaching.

\subsection{Developing Positive Professional Relationships}

The relationships between the twenty subject specific mentors employed on the project and the teachers in the 47 secondary schools was integral and purposely focused on as part of the broader project to make it successful (Conner, 2015). Mentors pro-actively worked on how they built positive rapport with the teachers who had chosen to be part of this PLD initiative. All of the mentors were recognized subject experts. Some of them have been national leaders in their subject specialisms. These mentors were also very well-experienced in working with adults as learners through their multiple interactions with many teachers in schools throughout NZ, and understood the principles of adult learning such as finding out what teachers knew already, valuing teachers' ideas and situating next steps in relation to the learners' needs and the consequential professional needs for each teacher. The mentors were also very aware of the need to support teachers as the experts who hold knowledge about their learners and their particular teaching contexts. This enabled and empowered teachers to be creative in how they targeted specific changes in their teaching in response to identifying their students' needs. The iterative discussions and feedback from mentors enabled them to make on-going refinements to their changes to pedagogical practices. A teacher commented about this:

This is the best PD I've ever had because it is tailored for me and my students and, by doing the tasks set (negotiated), my relationship with the 
students has immediately improved. This has improved the atmosphere in the class, and has given me information that allowed me to change my teaching to suit them, which they love. I have been very open with them that they are my PLD class, and I think they feel like we are all in this (research) together-I'm learning more about how to teach, they are learning more about learning and science, but we are all on a journey together. By having (my own) "homework", I've not been talked at (by my mentor) then left to do what I want with the information. I get feedback!!, and encouragement to try new things. It's also given a real structure to learning as inquiry. (Teacher)

Developing more positive relationships with her students led to students who had previously never achieved in science passing the national assessment tasks.

As illustrated by this teachers' statement above, the approach was a very layered, learner-centric model of PLD that built trust between the mentors and the teachers with iterations in the spirit of continuous improvement. In this way, teachers were empowered to make changes to their practices and identify what difference it made to students. When teachers were valued, given ideas to apply in practice and enabled to create their own solutions, and then saw success in relation to the changes they made to students, they were inspired to make further changes.

In general, teachers and school leaders highly valued the support they were given by the subject mentors. For example, a middle leader in a rural school indicated during her interview how, because of the focus on a small number of students, the inquiry seemed manageable and yet also transferrable. She stated:

I feel that a can-do attitude has been fostered through quality professional dialogue, a narrow and deep focus on target students and continued reflection around these individuals. Tools and resources have been provided to assist the achievement of this (focus) group and I have found that although the target is a small group (of students), the wider cohort all gain the benefits of the project and assistance I am being offered. (School leader)

The mentors also worked collaboratively as a team of 20 who connected informally as they worked in close or co-located work places. This involved sharing teachers' and students' success stories, problem solving specific difficult situations, developing resources collaboratively and sharing successful resources. In other words, the mentors were also enabled to be creative and develop resources in response to the needs of the teachers or science-focused clusters, rather than them implementing a pre-prescribed or formulaic PLD program.

There were many examples of where mentors made suggestions about how teachers could work more meaningfully together to improve the outcomes for priority learners. This included how heads of departments were encouraged by the mentors to discuss assessment activities, achievement data, changes to their localized curriculum implementation and specific literacy development within 
science with their staff. To help teachers be more critically reflective, the mentors often suggested that colleagues should help each other to identify what they were already doing that made a difference and then to discuss what the next steps might be for further improvements in student outcomes. This approach required schools and teachers enabling visits to each other's classrooms. One such example is provided in the following vignette as described by a mentor in her submitted vignette.

Vignette: Building positive relationships with colleagues

I encouraged a biology teacher to invite another teacher to observe her teaching in order to gather evidence related to what she was doing to meet the literacy needs of her students as she (her colleague) had identified that her focus students needed literacy support. The teacher asked that during the observation the observer could ask the students what they understood by the terms "describe and explain" that are used as sentence starters for the first and second levels of the achievement tasks in the NZ National Certificate of Educational Achievement assessments in biology.

The focus students indicated that they were uncertain what "describe and explain" might require in terms of a written biological answer. In fact, they thought that writing more made the answer a higher grade. They did not understand that they had to both express the concept and provide a reason or make connections between ideas to get full credit. This was somewhat of a surprise to the biology teacher. So, she decided to make this a focus of her inquiry for the rest of that year. She was able to identify this aspect due to her colleague's observations and their mutual trust about providing support for continuous professional learning. (Mentor)

Another example below was when a mentor suggested to a science teacher that she could use a more "place-based" approach to a very timely topic on earthquakes to make the learning situated and more experientially based and connected or authentic.

Vignette: Making links with a teacher and learners who have experienced earthquakes

The mentor discovered that a teacher from her science cluster in the North Island of New Zealand was preparing her students for an assessment about the February 2011 earthquakes in Christchurch, which is in the South Island. While the mentor could have suggested she pick a geological event that was more local, instead she suggested that perhaps this class could have a Skype conversation with a class in a Christchurch school where the mentor had previously taught. At the same time, the class in Christchurch was learning about the Greendale fault, which was the center of the September 2010 earthquake in Christchurch, so the timing coincided with their focus on earth science. The mentor put the two teachers in touch with each other. The students at the school in the North Island sent questions to the Christ- 
church class and the teachers set up a Skype connection during a lunchtime. This was a learning experience for the teachers as well. Students in the Christchurch school learned from having to answer questions on the earthquakes and both teachers felt it was a very worthwhile exercise. A number of the students in the North Island class commented on the value of the Skype experience in an evaluation of the unit. They now want to fly down and visit Christchurch with their teacher. The students, a small class of twelve, have even offered to pay for the teacher's teaching payment to release her to participate in this trip! (Mentor)

These examples above are examples from a wide range of situations that were identified where professional relationships made a difference both to teachers feeling empowered and that they had support and guidance to initiate new ways of viewing what they could do, thus increasing their creative capacity for pedagogical change.

\subsection{Developing Knowledge about Subject Content, Pedagogies and Implementing Changes}

As discussed above, the approach to TAI used in this project required teachers to use information directly related to students' learning and their learning needs to inform changes to practice. Teachers needed to be active learners themselves, as Levin (2003) has advocated for continuous professional learning. As part of this process, teachers identified what teaching behaviors made a difference, including connecting to students' interests for content and concept development, considered how the relationship approaches and experiential activities could be further enhanced and how other specific changes, such as inserting a literacy task within science, might make a difference. That is, changes in teaching were quite specific to content and learners' interests and needs. Teachers had to find out more information about their students. They did this in multiple ways such as looking at student work for evidence of concept understanding and literacy needs, talking to students to help them self-identify their needs, observing specific learning behaviors of students in their priority group and using both formative and summative assessment information. The following examples are taken from the science learning area.

Throughout the project the leaders and subject mentors were very aware of the importance of working with contextual similarities and differences amongst the schools. Multiple international studies (e.g. Carlson Powell, Short, \& Landes, 2002; Schleicher, 2013) have showed that content context was important for realizing the potential of changes to pedagogies and their transfer or adaptation to other contexts. Therefore, there was a need to understand the specificity or advice and guidance the mentors might give in relation to subject content (and science teaching related content in these examples provided in this paper) as well as other context characteristics of the learning environment including the learners, so that both successes and challenges could be identified. Seeking conclu- 
sions about effective pedagogies usually doesn't take account of how appropriate the pedagogy is for learning specific content (Schleicher, 2013). For schooling in New Zealand, it is important not only to get to know what interests individual students have but also what might support them in a broader sense to learn more effectively and use authentic learning contexts.

The vignette below is an example of where a science mentor challenged a teacher to change the context of a unit to make use of the cultural knowledge of her indigenous students.

Vignette: Changing the context to align with students' cultural knowledge

A science facilitator, who was working alongside a science department in a school with more than 50\% Māori students, discovered that the context the school had been using for a unit on micro-organisms was yoghurt. In an effort to find a context that used the students' cultural knowledge, a conversation with the science teachers revealed that a school family made Māori bread, Rewena. This bread, which uses a yeast-free sourdough, was then purchased at the local dairy and sampled by all present. A new unit was then written for micro-organisms with bread as the context instead of yoghurt. With some encouragement from the facilitator, the Head of Department asked a Pasifika student in her class about Samoan bread. As a result this student showed the teacher what was on the website about Samoan bread (reciprocal teaching) and the students' mother made Samoan bread for the class to study and sample. The students were very enthusiastic about this unit especially as they were making something they could eat but more importantly because it recognized and celebrated the Pasifika culture and not just the Māori culture. The Pasifika students took a real pride in sharing their culture and overall the grades for all the students were slightly higher than when yoghurt was used as the context. (Mentor)

Macfarlane (2004) provides a number of strategies for teachers to consider to help strengthen whanaungatanga which Bishop (1996) describes as, "the process of establishing relationships in a Māori context." One such strategy is to involve parents and families in their child's schooling. Macfarlane suggests that finding out about Māori families' backgrounds, their marae and their children can be done by making a phone call home and then visiting the home. The vignette below is an example of where a teacher contacted the student's family (whānau) to find out what would work, especially for their priority (indigenous) students.

\section{Vignette: Developing knowledge of the learner's needs}

The mentor, in discussion with the teacher about what information to collect in the first part of the TAI cycle, emphasized the importance of contacting whānau to help 'get to know the learners better.

As a result, the teacher rang the parents/guardians of all his indigenous students. One of these students had dyslexia and at the beginning of the year was completely disengaged in class. After speaking to his mother, the 
teacher decided to support the student in a more structured way by sending emails home that outlined the material for each lesson each night. This enabled the mother to read through the material with her daughter prior to class sessions as they had agreed during their telephone conversation. The student now arrives in class with a smile on her face and is more engaged in the lesson because she is pre-prepared. (Mentor)

Teachers also found it beneficial to discuss how they could improve students' language skills and understanding about concepts. This was especially important in science where some topics are riddled with new language and concepts that students needed help with. There were many literacy tools used to support aspects of reading, writing and communicating (please see Conner, 2015 for examples of these). We have included one specific example of a mentor vignette here to indicate how the inclusion of a literacy tool supported students' conceptual understanding and their consequent achievement in the topic test.

Vignette: A practical idea for learning new science language

Teachers identified that their focus students needed support with learning scientific vocabulary. After explaining that students needed more than a glossary to acquire scientific vocabulary, the mentor provided the teachers with some templates in a booklet which showed them how students could divide a notebook double page into four, write a new word across the center of the double page then, in each quadrant, process the word. The processing could include, for example, writing the definition, drawing a picture/diagram and labeling it, writing the word in a sentence and writing their own meaning of the word and/or in their own language. The plan was for students to choose to write words they didn't know the meaning of in their notebooks and use their own creativity to help them understand the meaning better.

During the teaching of genetics, one teacher adapted this 'practical idea' as discussed with the mentor. She asked her students to take a clean piece of paper, fold it in half and then half again and then unfold it. During each lesson (four per week) she gave the students a key word, like phenotype, to write in the middle of the paper. She provided time for the students to complete the quadrants, as suggested in a number of the templates provided. After this the piece of paper was pasted into the student books.

The teacher reflected that in her opinion, it was probably better to provide Year 10 students with the words rather than asking them to self-select. Students' oral feedback indicated that this was an enjoyable exercise, especially including an illustration of the idea. All of the students passed the end of topic assessment, which in previous years was not the case for this topic.

(Mentor)

The vignette above, not only illustrates a content context where a problem of practice was addressed through a small scale inquiry, but also illustrates how 
when teachers focused on a particular learning issue and used an intervention strategy, they could manage this if it was small enough to be "doable" but value it because it was "big enough" to make a difference to the outcomes of learners. Davey and Ham (2011) described this as the "Manageability" dimension of implementing pedagogical change.

Another illustration of how accessing knowledge that they could creatively apply to their teaching was provided by a teacher when she wrote about why she became involved in the project.

Mostly that last year I found the support I received very beneficial. TAI encouraged me to be more reflective about my teaching practice and provided support to plan and implement a unit. I am at a different school this year and felt like I needed help applying what I had learnt to the new context I found myself in. Incentives were having support to build a unit and have it critiqued and evaluated as I go but also the access to resources. Last year this meant for me physical things such as being able to color photocopy and laminate resources at UC Edplus but also accessing the knowledge people held in terms of engaging with our Māori community, Te Reo (Māori language and concepts), history of Papanui (local suburb), checking the literacy level of our tasks and working with the science mentor to find ways to rework activities to engage the students.

As a result of the changes this teacher made, she was able to identify through students' work, that they had improved their understanding about some science concepts.

There were a range of types of knowledge that benefitted teachers and students who were involved, including knowledge of learners, knowledge of what literacy tools might support learning in specific content areas, and cultural knowledge that supported teachers to connect more meaningfully with learners and their communities. Teachers were then enabled through participating in the project to take this knowledge and use it as they created new tasks in response to identifying their students' needs.

\subsection{Developing Student and Whānau (Family) Contributions to Inform Changes to Teaching}

Classroom teachers are the ones who should know their students and the vagaries and nuances of the context within which they are working the best. It is important then, that teachers listen to their students to enhance their knowledge and understanding of what is important for their students. Often parents or whānau (family) were contacted to find out if there were specific interests the students had or if there were special aspects related to the child's learning that needed to be taken into account. An example of this has been illustrated in a vignette above regarding a student with dyslexia.

Mentors provided a variety of tools to encourage teachers to gather student voice or feedback, for example, profile surveys (paper and on-line using Google 
Docs), as well as encouraging the teachers to talk to their students. The teachers' expertise in regard to this has developed much over the past five years as the repertoire of ideas across the project has been extended. A number of teachers commented about how much the students wanted them to know more about them and consequently these students have volunteered more information.

Participants in the implementation project (mentors, school leaders and teachers) were very aware of the importance of basing pedagogical changes in context, especially in relation to the needs of the students each teacher was working with, and the localized and personalized nature of the curriculum they were supporting teachers to modify or enhance. They were all very experienced teachers who could draw on a wide range of approaches to pedagogy due to their connections with multiple schools and their own professional learning and development. As a result of their previous experiences, they actively sought innovative ways for changes to practice and to monitor progress, using TAI. The changes to teaching often related to using more structured literacy tools, more structured feedback to students by giving them hints and specific instructions about what to do next (e.g. through Google Docs), using digital tools to provide more scaffolded learning tasks, more structured formative assessment, (as indicated in the mentor vignette below), the inclusion of culturally responsive approaches, of talking with students and actively seeking children's opinions about what their interests were and how they learn, to inform actions.

Vignette: Using Google Classroom to provide on-going feedback

A number of teachers are now using Google Classroom to provide on-going feedback to their students. As one teacher recently commented, "I don't want to take their books in to mark as that could leave them without their notes for several days." By using Google Classroom the teacher can monitor the progress of all his students and provide feedback in a timely manner to allow the students to constantly see this feedback in real time and use it to improve.

\section{Conclusion}

Teachers' knowledge of possible changes they could make, identifying students' needs and implementing and evaluating creative changes through the support of subject-specific mentors and their colleagues, was crucial to the success of TAI for improving students' outcomes. This was consistent with Kaser and Halbert's (2014: p. 215) assertion that "Inquiry actions can only be considered good if significant learner outcomes have improved". During the project, it became obvious that it was hard to measure some changes in outcomes such as levels of enthusiasm and emotional engagement. However, our evidence related to teachers reporting higher cognitive participation of their priority students and attributed these directly to the creative changes they had implemented.

The analysis across 47 schools and multiple examples presented in this paper, showed that the key factors for enabling teachers to be creative in their solutions 
for addressing the needs of their indigenous students were: the development of positive professional relationships; developing pedagogical knowledge; implementing changes that incorporated a TAI reflection and evaluation process and encouraging the use of student and whānau (family) voice or feedback to inform changes to teaching.

The examples provided here and from the broader study (Conner, 2015) indicated that teachers were provided with opportunities for:

1) Professional dialogues about what could be done;

2) Reconsidering professional practice as a creative way to support students' learning;

3) Developing a deeper perspective of issues related to priority students' learning;

4) Providing ideas for change and a consideration of alternative solutions; and

5) Aligning small changes to practice with improved student outcomes.

It is critical that through supported professional learning, teachers are empowered to be creative in the pedagogical solutions they develop through critical inquiry into the shared meaning, purpose and nature of the evidence they obtain (Timperley, 2011). Teachers appreciated having someone to discuss their identified issues with mentors and colleagues, and to work together on alternative possibilities for refinements to teaching. Further, when the outcomes of such inquiries were shared amongst staff, both within their own schools and through subject cluster groups, there were likely to be greater contributions made to teaching as a profession more generally (system lift). The improved cognitive and emotional engagement of students was likely in response to the improved engagement of teachers and reported changes to levels of reflection using evidence, as a result of the teachers' inquiry of their own practices. Teacher enthusiasm and role modeling their own willingness to consider alternatives as continuous professional learning should not be underestimated. Students know when their teachers are interested in them and care about their achievement.

In contrast, there was less success in departments where there was not strong leadership or where the directions of the department were at odds with the TAI whole-school process. Keeping perspective and focusing on improvements that would make the most difference for students, seemed to increase the chances of improved students' outcomes. As Timperley, Kaser and Halbert (2014: p. 10) note, "Focused and deep rather than scattered and shallow is the goal."

Culturally responsive practices in schools have been shown to be an effective way of reducing the long tail of underachievement (Griner \& Stewart, 2013) but enabling teachers to make a paradigm shift to culturally responsive teaching is a huge challenge. Because teachers in this study chose their own focus for inquiry related to the needs of their students, there was a wide range of ways teachers evaluated teaching and learning successes. The lack of consistency in information, even within a particular department, is a limiting factor of this research and made collating examples of change messier. One of the improvements suggested 
by several heads of department was for the teachers within a department to agree ahead of the next inquiry cycle, about what evidence they would use to:

1) Measure their own success in implementing change and

2) Evaluate what effect small changes in teaching had on specific students' outcomes.

This paper has provided examples of how teachers linked changes in their approaches to teaching Māori and Pasifika students in particular, to changes in students' outcomes, which has rarely been reported previously, withstanding the limitations of using narratives for reporting change. As Loucks-Horsley (1996: p. 5) stated "just as continuous formative assessment is imperative in science and mathematics classrooms, monitoring teacher experiences in professional development provides opportunities to constantly improve them". Then, when professional advances are linked to teachers' observations of changes in students' outcomes, there is a much more powerful incentive to make ongoing enhancements to their teaching through further observations and changes. In other words, teachers' success with TAI provides motivation for them to make further iterations to their teaching which can lead to further students' success. It may also lead to greater teacher satisfaction and additional ways teachers can creatively affect improved student outcomes. More opportunities to share and extend how teachers create effective learning experiences for Māori and Pasifika, are likely to enhance and spread effective approaches and consequential system lift.

\section{References}

Akharvan, N. (2015). Coaching Side-by-Side. Journal of Staff Development, 36, 34-45.

Benade, L. (2015). Teaching as Inquiry: Well Intentioned, but Fundamentally Flawed. New Zealand Journal of Educational Studies, 50, 107-120. https://doi.org/10.1007/s40841-015-0005-0

Bishop, R. (1996). Collaborative Research Stories: Whakawhanaungatanga. Palmerston North, New Zealand: The Dunmore Press.

Blankstein, A. M., \& Noguera, P. (2015). Achieving Excellence through Equity for Every Student. In A. M. Blankstein, \& P. Noguera (Eds.), Excellence through Equity: Five Principles of Courageous Leadership to Guide Achievement for Every Student (pp. 3-30). Thousand Oaks, CA: Corwin/Sage.

Brookfield, S. (1995). Becoming a Critically Reflective Teacher. San Francisco, CA: Jossey-Bass.

Carlson Powell, J., Short, J. B., \& Landes, N. M. (2002). Curriculum Reform, Professional Development and Powerful Learning. In R. W. Bybee (Ed.), Learning Science and the Science of Learning: Science Educators' Essay Collection (p. 121). http://www.eblib.com

Committee, House of Representatives Education and Science (2008). Inquiry into Making the Schooling System Work for Every Child. https://www.parliament.nz/resource/en-nz/48DBSCH_SCR3979_1/383847d373839d32 1e886e1754d8378732ad69e6

Conner, L. N. (2013). Meeting the Needs of Diverse Learners in New Zealand. Preventing 
School Failure, 57, 157-161. https://doi.org/10.1080/1045988X.2013.795927

Conner, L. N. (2015). Teaching as Inquiry with a Focus on Priority Learners. Wellington: NZCER Press.

Conner, L. N., \& Bennetts, J. (2016). Mentoring Teaching as Inquiry with a Focus on Priority Learners. In ECER 2016 Leading Education: The Distinct Contributions of Educational Research and Researchers. University College Dublin, Ireland: European Educational Research Association. European Council of Educational Research Annual Conference, Dublin, Ireland.

Conner, L. N., \& Sliwka, A. (2014) Implications of Research on Effective Learning Environments for Initial Teacher Education. European Journal of Education, 49, 165-177. https://doi.org/10.1111/ejed.12081

Cooper, G. (2012). Kaupapa Maori Research: Epistemic Wilderness as Freedom? New Zealand Journal of Educational Studies.

Cooperrider, D. L., Sorensen, P. F., Whitney, D., \& Yaeger, T. T. (Eds.) (2000). Appreciative Inquiry: Rethinking Human Organisation towards a Positive Theory of Change. Champaign, IL: Stripes Publishing.

Cowie, B., Otrel-Cass, K., Glynn, T., H., Kara, Anderson, M., Doyle, J. et al. (2011). Culturally Responsive Pedagogy and Assessment in Primary Science Classrooms. Whakamana tamariki.

http://www.tlri.org.nz/tlri-research/research-completed/school-sector/culturally-respo nsive-pedagogy-and-assessment-primary

Davey, R., \& Ham, V. (2011). "It's All about Paying Attention"...but to What? The "6 Ms" of Mentoring the Professional Learning of Teacher Educators. In T. Bates, A. Swennen, \& K. Jones (Eds.), The Professional Development of Teacher Educators (pp. 232-247). London and New York: Routledge.

Day, C. (1999). Developing Teachers: The Challenges of Lifelong Learning. London, UK: Falmer.

Dewey, J. (1933). How We Think. A Restatement of the Relation of Reflective Thinking to the Educative Process. Boston, MA: DC Heath and Company.

Education Review Office (ERO) (2011). Directions for Learning. The New Zealand Curriculum Principles and Teaching as Inquiry. Wellington, New Zealand: ERO.

Education Review Office (ERO) (2012). Teaching as Inquiry: Responding to Learners. Wellington, New Zealand: ERO.

Ell, F., \& Grudnoff, L. (2013). The Politics of Responsibility: Teacher Education and "Persistent Underachievement" in New Zealand. The Educational Forum, 77, 73-86. https://doi.org/10.1080/00131725.2013.739023

Garet, M., Porter, A., Desimone, L., Birman, B., \& Yoon, K. S. (2001). What Makes Professional Development Effective? Results from a National Sample of Teachers. American Educational Research Journal, 38, 915-945. https://doi.org/10.3102/00028312038004915

Griner, A. C., \& Stewart, M. L. (2013). Addressing the Achievement Gap and Disproportionality through the Use of Culturally Responsive Teaching Practices. Urban Education, 48, 585-621. https://doi.org/10.1177/0042085912456847

Guskey, T. R. (2003). What Makes Professional Development Effective? Phi Delta Kappan, 84, 748-750. https://doi.org/10.1177/003172170308401007

Hipkins, R. (2015). Learning to Learn in Secondary Classrooms. Wellington, New Zealand: New Zealand Council for Educational Research. 
Jansen, C., Cammock, P., \& Conner, L. N. (2010). Leaders Building Professional Learning Communities: Appreciative Inquiry in Action. Journal of Educational Leadership, Policy and Practice, 25, 41-54.

Kaser, L., \& Halbert, J. (2014). Creating and Sustaining Inquiry Spaces for Teacher Learning and System Transformation. European Journal of Education, 49, 206-217. https://doi.org/10.1111/ejed.12079

Levin, B. (2003). Case Studies of Teacher Development: An In-Depth Look at How Thinking about Pedagogy Develops over Time. Mahwah, NJ: Lawrence Erlbaum Associates.

Lieberman, A., \& Miller, L. (Eds.) (2001). Teachers Caught in the Action: Professional Development That Matters. New York: Teachers College Press.

Loucks-Horsley, S. (1996). Professional Development for Science Education: A Critical and Immediate Challenge. In R. Bybee (Ed.), National Standards and the Science Curriculum (pp. 83-95).

Macfarlane, A. (2004). Kia hiwa rā! Listen to Culture: Mãori Students' Plea to Educators. Wellington, New Zealand: NZCER Press.

Ministry of Education (2007). The New Zealand Curriculum. Wellington, New Zealand: Ministry of Education.

Ministry of Education (2009a). Teachers as Learners: Improving Outcomes for Māori and Pasifika Students through Inquiry. Wellington, New Zealand: Learning Media Ltd.

Ministry of Education (2012a). Ka Hikitia-Accelerating Success 2013-2017: The Mãori Education Strategy. Wellington, New Zealand: Ministry of Education. https://www.education.govt.nz/ministry-of-education/overall-strategies-and-policies/p asifika-education-plan-2013-2017/

Ministry of Education (2012b). Pasifka Education Plan 2013-2017. Wellington, New Zealand: Ministry of Education.

Ministry of Education (2016). Ambitious for New Zealand: The Ministry of Education Four Year Plan 2016-2020. Wellington, New Zealand: Ministry of Education.

New Zealand Teachers Council (2010). Tãtaiako-Cultural Competencies for Teachers of Māori Learners.

https://educationcouncil.org.nz/required/Tataiako.pdf

OECD (2010). The Nature of Learning: Using Research to Inspire Practice. Paris: Educational Research and Innovation OECD Publishing. http://www.oecd.org/education/ceri/50300814.pdf

OECD (2013). Innovative Learning Environments. Paris, France: Educational Research and Innovation, OECD Publishing. https://doi.org/10.1787/9789264203488-en

Schleicher, A. (Ed.) (2013). Preparing Teachers and Developing School Leaders for the $21^{\text {st }}$ Century: Lessons from around the World. Paris: OECD Publishing. http://www.oecd.org/site/eduistp2012/49850576.pdf

Sinnema, C., \& Aitken, G. (2011). Teaching as Inquiry in the New Zealand Curriculum: Origins and Implementation. In J. Parr, H Hedges, \& S. May (Eds.), Changing Trajectories of Teaching and Learning (pp. 29-48). Wellington: NZCER Press.

Timperley, H. (2011). Realizing the Power of Professional Learning. Maidenhead: Open University Press.

Timperley, H., Wilson, A., Barrar, H., \& Fung, I. (2007). Teacher Professional Learning and Development: Best Evidence Synthesis Iteration. Wellington: Ministry of Education. 
Webster-Wright, A. (2009). Reframing Professional Development through Understanding Authentic Professional Learning. Review of Educational Research, 79, 702-739.

https://doi.org/10.3102/0034654308330970 